\title{
Presentasi Perempuan dalam Perspektif Ekofeminisme pada Film Marlina Si Pembunuh dalam Empat Babak
}

\author{
Resky Apriliani Basnapal1 \\ Communication Studies, Faculty of Communication \& Business, Telkom University \\ Bandung, Indonesia \\ (reskyaprilianib@gmail.com) \\ Roro Retno Wulan \\ Communication Studies, Faculty of Communication \& Business, Telkom University \\ Bandung, Indonesia \\ (rorowoelan28@gmail.com/rorowoelan@telkomuniversity.ac.id)
}

\begin{abstract}
This study aims to describe the women depicted in the film "Marlina, the murderer in four rounds". The film discusses Marlina's struggle in the form of domination carried out by robbers. Marlina here is analogized as a natural management woman who is ready to fight against the patriarchal system. This research is based on the study of ecofeminism which is divided into three perspectives that will become the eyes of researchers, namely knowledge, intuition, and spiritual. Using qualitative research methods with Roland Barthes's semiotic approach. The data sources used are primary data, and secondary data through literature studies such as journals, theses, papers, books, and so on. The results of the study show that Marlina as a natural manager is analogous to no-man's land, trade products, producers / births can be mastered, oppressed, or exploited. This cause natural imbalances such as disasters that Marlina represents for Mark's death.
\end{abstract}

Keyword : ecofeminism, women, nature, film, roland barthes's semiotics

\begin{abstract}
Abstrak. Penelitian ini bertujuan untuk mendeskripsikan presentasi perempuan yang digambarkan dalam film "Marlina, si pembunuh dalam empat babak". Film ini memperlihatkan perjuangan Marlina dalam melawan bentuk dominasi yang dilakukan oleh para perampok. Marlina di sini dianalogikan sebagai perempuan pengelolah alam yang siap bertempur melawan sistem patriarki. Penelitian ini berlandasan pada kajian ekofeminisme yang dibagi ke dalam tiga perspektif yang akan menjadi kaca mata peneliti yaitu pengetahuan, intuisi, dan spiritual. Menggunakan metode penelitian kualitatif dengan pendekatan semiotika Roland Barthes. Sumber data yang digunakan adalah data primer, dan data sekunder melalui studi pustaka seperti jurnal, skripsi, paper, buku, dan lain sebagainya. Hasil penelitian menunjukkan bahwa Marlina sebagai pengelolah alam yang dianalogikan sebagai tanah tak bertuan, produk dagang, penghasil/melahirkan dapat dikuasai, ditindas, maupun dieksploitasi. Hal tersebut akan menyebabkan ketidakseimbangan alam seperti bencana yang direpresentasikan dari perlawanan Marlina atas kematian Markus.
\end{abstract}

Kata Kunci : ekofeminisme, perempuan, alam, film, semiotika roland barthes

\footnotetext{
${ }^{1}$ Penulis korespondensi 


\section{Pendahuluan}

Film merupakan media penyampaian pesan yang memiliki peranan penting dalam pembentukan opini di masyarakat. Salah satunya yang selalu menjadi objek dalam film adalah perempuan. Adi Kurnia D.N (2013) dalam Chandraningrum (2014:293) mengungkapkan bahwa perempuan dalam media massa digunakan sebagai suatu 'alat' atau 'objek jualan' yang memberikan nilai tambah dalam suatu media tertentu.

Narasi umum film di Indonesia maupun di dunia selalu menunjukkan pusat perhatian dan tokoh utama terhadap lakilaki, dan sebaliknya selalu mencirikan sosok perempuan yang lemah dan selalu membutuhkan pertolongan laki-laki. Film "Marlina, si pembunuh dalam empat babak" ini berbeda. Unsur feminis sangat jelas ditampilkan dalam setiap adegan film. Alhasil, film ini banyak mendapatkan penghargaan, baik nasional maupun internasional karena alur cerita yang menarik dan latar belakang budaya Sumba yang unik.

Film ini berdurasi 1 jam 33 menit. Ia dibagi dalam empat babak, yaitu babak pertama perampokan, babak kedua perjalanan, babak ketiga pengakuan, dan babak keempat kelahiran. Setiap adegan dalam film menunjukkan banyaknya perlakuan kekerasan, penindasan, dan pemerkosaan yang mengobjektifitaskan Marlina sebagai perempuan pengelola alam.

Film "Marlina, si pembunuh dalam empat babak" ini, menceritakan seorang perempuan janda bernama Marlina yang mempertahankan harga dirinya dari para perampok yang hendak mengontrol dan menguasainya. Sosok Marlina yang ditampilkan dalam film ini hidup mandiri tanpa bantuan laki-laki, serta memiliki keberanian untuk melawan ketidakadilan para perampok. Hal ini terlihat pada babak pertama yang menunjukkan perlakuan kekerasan, penindasan, dan ketidakadilan yang didapatkan oleh Marlina. Narasi ini menunjukkan kaum laki-laki memiliki kedudukan yang lebih tinggi ketimbang perempuan. Marlina berani bangkit untuk mempertahankan harga dirinya sebagai seorang perempuan dan pengelola alam dengan membunuh para perampok.

Latar tempat pembuatan film "Marlina, si pembunuh dalam empat babak" ini adalah Sumba (Nusa Tenggara Timur). Sumba memiliki sistem patriarki yang tinggi yang tampak dari, misalnya, dalam pergeseran makna adat perkawinan yang dikenal sebagai belis.

Belis ini adalah mahar yang harus dibayar berupa sejumlah uang, binatang ternak, kain tenun, dan mamoli. Ia awalnya digunakan sebagai penghormatan bagi perempuan karena perempuan merupakan aset berharga bagi rumah tangga, pekerja yang tekun yang melahirkan generasi selanjutnya. Namun, saat ini, terdapat pergeseran makna, di mana belis menempatkan perempuan sebagai sebuah produk dagang. Pergeseran makna belis memunculnya banyaknya kasus di mana perempuan menjadi objek kekerasan karena laki-laki merasa telah membayar lunas belis tersebut.

Nafi dan kawan-kawan (2016:249) yang mewawancarai salah satu tokoh masyarakat Sumba bernama Umbu Guntur menuliskan bahwa di Sumba Timur tidak ada kekerasan terhadap perempuan. Namun, ketiadaan kekerasan ini sebenarnya karena semata tindakan tersebut dilegalkan oleh adat. Wanita di Sumba memiliki tingkatan sosial yang rendah sehingga dianggap layak diperlakukan kasar.

Dengan kebiasaan tersebut, pada 2017, Kabupaten Sumba Timur menempati urutan kedua kasus kekerasan terhadap 
perempuan dan anak setelah Kota Kupang. Di Sumba Timur, terdapat 73 kasus kekerasan terhadap perempuan dan anak di tahun tersebut sebagaimana disampaikan Sekretaris Dinas Pemberdayaan Perempuan, Perlindungan Anak Pengendalian Penduduk, dan Keluarga Berencana (DP3AP2KB) Kabupaten Sumba Timur Lapu R Yona (Johannis, 2018)

Mulyoutami dan kawan-kawan (2016:30) yang melakukan diskusi di 6 desa di Sumba menunjukkan bahwa di 3 desa partisipasi perempuan rendah di mana pembicaraan didominasi pihak lakilaki. Sementara 3 diskusi di desa lainnya, menunjukkan beberapa perempuan lebih berani bicara walau hanya dua hingga tiga orang saja. Keterlibatan perempuan yang berada di Sumba sangat kurang di ranah publik karena pengetahuan yang rendah dan ketakutan mengemukakan pendapat di depan umum.

Sebagian besar masyarakat Sumba memegang kepercayaan Marapu. Ini merupakan ajaran para leluhur melalui perayaan upacara, ritual, dan pengorbanan untuk penghormatan kepada sang pencipta arwah para leluhur. Bisa dikatakan bahwa agama marapu ini merupakan inti kebudayaan, nilai-nilai, dan pandangan hidup serta mempunyai pengaruh yang besar terhadap kehidupan masyarakat Sumba. Kebudayaan ini juga mengobjekkan perempuan Sumba sehingga tidak memiliki ruang yang bebas dalam melakukan segala sesuatu.

Atas dasar latar tersebut, Film Marlina menjadi unik. Pembentukan karakter Marlina dalam film ini dipengariuhi oleh lingkungannya yang sangat patriarkal. Tak ayal, Marlina yang memiliki sifat pemberani, tegas, dan mandiri tanpa bantuan laki-laki menjadi menarik.
Salah satu konsep dalam feminisme, yaitu ekofeminisme penting untuk membedah film ini. Ekofeminisme adalah sebuah konsep mengenai perempuan yang selalu dianalogikan sebagai alam. Jadi, ketika alam rusak maka perempuanlah yang terkena dampaknya secara langsung. Menurut Tong (dalam Pondaag 2016: 108), ekofeminisme berpendapat tentang adanya hubungan konseptual, simbolik, dan linguistik antara feminisme dan isu ekologi.

Isu ekologi di sini diartikan bahwa secara tidak sadar perempuan telah "dinaturalkan" (saat manusia diperlakukan sebagai binatang) dan alam telah "difemininkan" (alam ditambang, dikuasai dan ditaklukkan oleh laki-laki). Konsep "difemininkan" dalam film ini ditunjukkan pada adegan ketika Markus ingin menguasai seluruh kekayaan baik uang dan binatang ternak hingga kehidupan yang dimiliki oleh Marlina. Konsep dinaturalkan dalam film, di sisi lain, dapat ditunjukkan ketika Markus melakukan tindakan kekerasan dan pemerkosaan kepada Marlina. Dalam film ini, diperlihatkan perlawanan Marlina untuk melawan dominasi patriarki yang dilakukan oleh Markus dan temantemannya untuk mendapatkan keadilan, dan mendapatkan posisi yang layak di masyarakat.

Hal ini memiliki kesamaan dengan film Malefincent (Pondaag, 2017). Malefincent melakukan perlawanan terhadap bentuk dominasi yang dilakukan oleh raja. Perempuan dalam film tersebut digambarkan sebagai sosok yang kuat, tapi masih saja dianggap lemah sehingga lakilaki memiliki kesempatan untuk mendominasinya.

Berbeda dengan kehidupan perempuan di perkebunan teh (Wulan, 2018) di mana perempuan hanya diam terhadap ketidakadilan upah dan kerja keras yang mereka lakukan sebagai pemetik teh, Marlina melawan bentuk dominasi 
tersebut.

Faktanya kasus-kasus perempuan di Sumba sering diselesaikan dengan cara hukum adat atau kekerabatan (Nafi et al., 2016). Sistem kekerabatan yang masih sangat erat menyebabkan penggunaan hukum adat dan membuat kerugian sepihak kepada perempuan meskipun kasus yang tidak dapat diselesaikan secara adat, biasanya pembunuhan ataupun pemerkosaan, oleh sebagian besar warga Sumba dibawa ke ranah hukum negara.

Peneliti melihat adanya pengaruh lingkungan alam dalam membentuk karakter Marlina yang ditampilkan dalam film. Peneliti ingin melihat bagaimana teks media memperlihatkan tanda dan lambang mengenai perempuan yang berkaitan dengan perempuan sebagai pengolah alam. Peneliti ingin meneliti presentasi yang ditampilkan dalam film melalui kaca mata ekofeminisme yang dibagi menjadi 3 perspektif, yaitu pengetahuan, intuisi dan spiritual. Oleh karenanya, rumusan masalah dalam artikel ini adalah bagaimana representasi pengetahuan, spiritual dan intuisi perempuan pada film "Marlina, si pembunuh dalam empat babak”?

\section{Metode Penelitian}

Metode Penelitian yang digunakan dalam penelitian ini adalah metode penelitian kualitatif dengan pendekatan semiotika Roland Barthes.

Penelitian kualitatif merupakan metode penelitian yang digunakan untuk meneliti kondisi objek penelitian, di mana peneliti bertindak sebagai instrumen kunci, pengambilan contoh dan data, teknik pengumpulan data dilakukan dengan triangulasi atau gabungan, analisis data, dan hasil penelitian kualitatif lebih menekankan pada makna daripada generalisasinya (Sugiono, 2009:15).
Dalam penelitian ini, peneliti menggunakan paradigma konstruktivisme untuk membangun makna baru dalam presentasi perempuan dalam perspektif ekofeminisme pada film "Marlina, si pembunuh dalam empat babak". Selain itu, penulis juga menggunakan triangulasi sumber sebagai teknik keabsahan data.

\section{Hasil Dan Pembahasan}

Hasil temuan dari analisis denotasi, konotasi serta penelusuran skripsi, jurnal, internet maupun buku yang berkenaan mengenai Sumba Timur maka peneliti menemukan tiga mitos yang berada di Sumba Timur yang berkaitan dengan dominasi dalam film "Marlina, si pembunuh dalam empat babak", yaitu berhubungan dengan iklim lingkungan yang berada di Sumba, sistem belis, dan kepercayaan Marapu masyarakat Sumba.

Tiga mitos tersebut menunjukkan bagaimana perempuan dalam dibentuk oleh tiga dimensi ideologi berdasarkan perspektif ekofeminisme, yaitu pengetahuan, intuisi, dan spiritual.

Dimensi Pengetahuan dalam ekofeminisme di sini dapat dilihat dari sudut pandang Marlina sebagai seorang perempuan yang dibentuk oleh pengalaman-pengalaman pribadinya berhadapan dengan lingkungan. Jadi pada dimensi pengetahuan, mitos dihubungkan dengan kondisi iklim lingkungan yang berada Sumba Timur.

Dimensi intuisi dapat dilihat dari pembacaan situasi atau kepekaan dari Marlina maupun Novi. Perasaan maupun firasat dalam pengambilan keputusan untuk memperjuangkan hak, melawan bentuk dominasi yang dilakukan oleh lakilaki dalam realitas adat Sumba di mana terdapat bibit patriarki. Intuisi di sini akan dikaitkan dengan mitos mengenai sistem belis yang berada di Sumba. 
Aspek spiritual menurut salah satu tokoh ekofeminisme, yaitu Vandana Shiva dan Mies (dalam Chandraningrum 2013: 130) adalah "kasih". Tanpa kasih tidak akan ada kehidupan yang berkembang. Spiritual adalah magis yang terkandung dalam segala sesuatu. Perempuan memiliki peran yang signifikan yang dapat mengubah alam dan bumi menjadi lebih harmonis dan akrab dengan cara mengedepankan sisi feminitas: lemah lembut, kasih sayang dan anti dominasi. Pengertian spiritual yang telah dijelaskan oleh Shiva dan Mies di atas mengenai magis ini akan dikaitkan dengan kepercayaan Marapu yang memiliki sifat magis di dalamnya.

\section{Mitos Iklim/Lingkungan Pembentuk Pengetahuan Perempuan}

Latar film "Marlina, si pembunuh dalam empat babak" adalah bukit Savana Sumba yang gersang. Iklim Sumba sangat panas dan kadang menyebabkan kekeringan yang sangat panjang. Iklim di kawasan Sumba Timur umumnya gersang atau biasa disebut juga iklim semi arid. Menurut Mudita (Chandraningrum 2013: 247), kata arid dalam konteks iklim, digunakan untuk menyatakan keadaan yang merujuk pada suatu ratio rerata presipitasi tahunan (meliputi curah hujan, embun, salju) terhadap evapotranspirasi tahunan (meliputi penguapan dari badan perairan terbuka dan penguapan makhluk hidup).

Sumba memiliki iklim musim hujan yang relatif pendek, yaitu sekitar 3-4 bulan saja. Sumba juga memiliki musim kemarau yang panjang, yaitu sekitar 8-9 bulanan. Iklim lingkungan yang gersang di Sumba ini merepresentasikan juga kesulitan kehidupan perempuan yang berada di Sumba.
Para perempuan Sumba memiliki pekerjaan yang lebih banyak dibandingkan dengan laki-laki. Mereka harus memenuhi pekerjaan domestik seperti penyediaan pangan dan air. Keadaan iklim Sumba ini membuat perempuan susah mendapatkan air bersih untuk kebutuhan rumah tangganya.

Salah satu penyebab kekeringan adalah campur tangan manusia yang berciri maskulin. Manusia yang berpaham patriarki dan kapitalis yang hanya mengambil keuntungan tanpa memperhatikan dampak yang akan terjadi ke depannya. Ini didukung teori yang dijelaskan oleh Chandraningrum (2013:3) bahwa perubahan iklim merupakan fenomena yang salah satunya disebabkan oleh aktivitas manusia dan kegiatan alam itu sendiri.

Perebutan tanah, di masa lalu, selalu ada di Sumba. Perebutan tanah ini biasanya dimulai dengan peperangan dengan penduduk yang bertempat tinggal di suatu daerah tertentu. Pemenang akan membuat hierarki dalam struktur sosial masyarakat. Mereka masuk dalam golongan elite atau bangsawan (maramba).

Perebutan tanah di Sumba yang dilakukan oleh kaum maskulin juga dapat dilakukan pada perempuan. Maskulinitas menganggap bahwa suatu lahan yang ia miliki dapat ia manfaatkan untuk keuntungan pribadi, demikian juga terhadap perempuan.

Ini juga direpresentasikan dalam film tatkala adegan Markus memperlakukan Marlina layaknya sebuah lahan yang baru. Marlina harus siap "digarap” dan diambil keuntungan baginya tanpa memperdulikan dampaknya.

Masyarakat Sumba memiliki tiga mata pencarian, yaitu bertani (berbeda dengan pertanian pada umumnya di Indonesia, pertanian di Sumba merupakan 
pertanian kering), berkebun, dan menenun (dilakukan oleh perempuan). Dari pekerjaan bertani ini, binatang ternak yang berada di Sumba merupakan suatu simbol sosial keluarga dan masyarakat Sumba (Onvlee 198, Melalatoa 1995) dalam Mulyoutami et al., et al., (2016: 114). Kepemilikan ternak, dengan demikian, mencerminkan kepemilikan barang atau properti hidup. Semakin banyak properti yang dimiliki maka semakin tinggi status sosial yang melekat.

Sumba memiliki tingkat ekonomi dan pendidikan yang rendah. Hal ini disebabkan salah satunya lingkungan iklim yang berat untuk pengolahan ekonomi, dan karena jarak antara perumahan dan sekolah yang cukup jauh sehingga banyak anak yang berada di Sumba putus sekolah.

Salah satu penyebab kemiskinan di Sumba, yaitu berbagai adat atau ritual tertentu yang mengharuskan untuk mengeluarkan banyak dana. Salah satunya ritual penguburan untuk orang yang meninggal. Ini juga digambarkan dalam film. Keadaan ekonomi Marlina terlihat dari mayat suami Marlina yang sudah kaku. Kakunya mayat itu menunjukkan mayat itu sudah lama disimpan di rumah. Masalah ekonomi yang dihadapi oleh Marlina ini mengharuskan ia mandiri. Tingkatan sosial ekonomi dan kebiasan masyarakat Sumba ini menjadi faktor penindasan perempuan dan alam di Sumba. Dalam film ini, Markus melihat keadaan ekonomi Marlina yang kurang mampu dan tidak mempunyai perlindungan seorang laki-laki dalam rumahnya karena suaminya telah meninggal. Markus melihat ketidakberdayaan Marlina untuk melawannya. Lalu, muncul dominasi darinya untuk memperlakukan Marlina dan alam semena-mena layaknya seorang budak.
Dalam lingkungan masyarakat Sumba, ada 3 golongan yang dikenal dalam tingkatan sosial. Golongan paling atas disebut sebagai maramba (kaum bangsawan), golongan menengah yaitu masyarakat biasa disebut kabihu di Sumba Timur, dan golongan yang paling rendah, yaitu budak disebut ata dalam Bahasa Sumba. Tingkatan sosial yang ada di masyarakat Sumba inilah yang menjadi salah satu penyebab adanya perbedaan tindakan kekerasan dan perlakuan yang semena-mena terhadap perempuan dan juga alam.

Perbedaan tingkatan sosial ini menyebabkan perlakuan kasar adalah hal lumrah. Lumrah karena adat Sumba menganggap sebagai sebuah kebiasaan, di mana semakin rendah tingkatan sosialnya akan rentan terhadap kekerasan.

Di Sumba Timur, proses penyelesaian masalah selalu diputuskan tetua adat. Dalam kasus kekerasan perempuan, tetua adat bahkan tidak menghiraukan kepentingan perempuan yang menjadi korban. Dalam kasus pemerkosaan, misalnya, seringkali perempuan korban pemerkosaan harus dinikahkan dengan pelaku. Apabila hal itu tidak dilakukan maka akan menjadi sebuah aib bagi keluarga perempuan.

Hal ini menimbulkan permasalahan baru bagi korban perempuan. Tidak heran, Sumba menempati urutan kedua dalam kasus kekerasan terhadap perempuan sebagaimana disampaikan oleh Sekretaris Dinas Pemberdayaan Perempuan, Perlindungan Anak Pengendalian Penduduk, dan Keluarga Berencana (DP3AP2KB).

Mitos tetang iklim lingkungan dan dampak-dampak yang muncul dari keadaan lingkungan di atas mengkonstruksi pengetahuan pribadi Marlina. Kondisi kesulitan yang dihadapi oleh Marlina tercermin dari lingkungan yang ada di Sumba. 
Faktor ekonomi dan tingkatan sosial di masyarakat menyebabkan adanya perbedaan perlakuan kepada perempuan. Pembagian kerja atas laki-laki dan perempuan menunjukkan kedekatan alam yang signifikan pada perempuan karena perempuan selalu dikaitkan dengan pekerjaan domestik.
Kondisi ini membentuk sudut pandang yang berbeda antara laki-laki dan perempuan dalam melihat persoalan krisis lingkungan di Sumba. Sudut pandang yang berbeda inilah yang menjadi akar eksploitasi manusia dan kekerasan gender. Secara singkat, dapat dilihat pada gambar berikut yang di olah oleh peneliti.

Gambar 1. Mitos Iklim lingkungan Pembentuk Pengetahuan Marlena (Sumber: Hasil Riset, 2018)

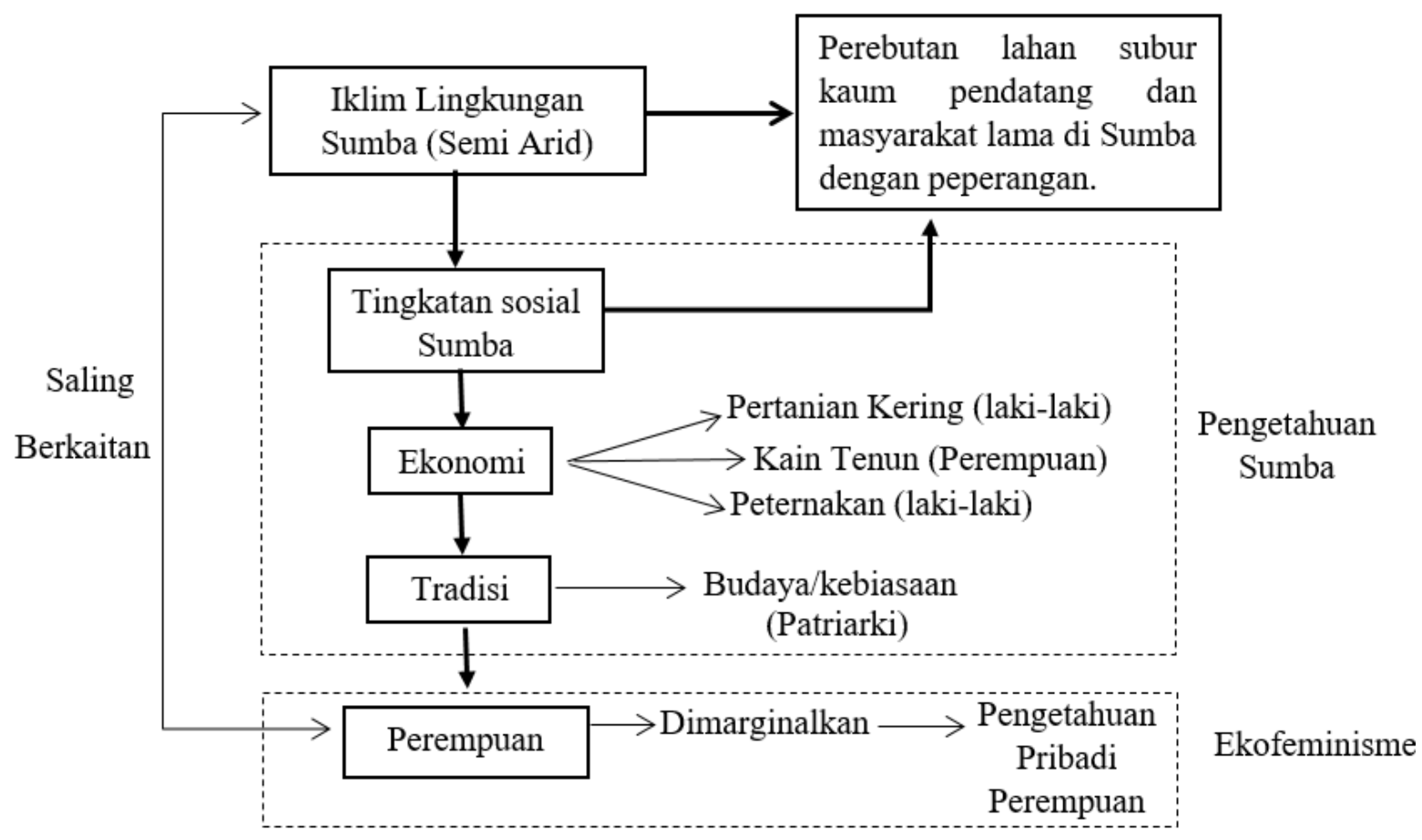

Marlina dalam film dianalogikan sebagai sebuah tanah tak bertuan. Marlina dapat dikuasai, dijajah, diperkosa, atau bahkan diambil kekayaannya. Dalam perspektif ekofeminisme, perempuan merupakan pelindung alam dan apabila alam mengalami ketidakseimbangan maka akan terjadi sebuah bencana. Bencana tersebut dapat ditandai dengan kematian Markus, para perampok, Frans, maupun pemberontakan yang dilakukan oleh Novi.

\section{Mitos Sistem Belis}

Di Sumba Timur, juga dikenal dengan proses meminang seorang perempuan dengan sebutan sistem belis. Belis adalah besaran mahar atau mas kawin yang diberikan oleh pihak laki-laki kepada perempuan sesuai hasil ketentuan yang telah disepakati oleh pihak perempuan. Belis berupa sebuah hewan ternak (seperti kuda, sapi, kambing, maupun babi), uang logam (emas, ataupun perak), parang, mamoli dan kain tenun. Dalam acara pernikahan, masyarakat Sumba kedudukan pihak pemberi lebih tinggi dibandingkan dengan pihak penerima. Keduanya dilakukan oleh perempuan yang dianggap sebagai orang yang melahirkan generasi selanjutnya. 
Dalam masyarakat Sumba, belis digunakan sebagai penghormatan bagi perempuan karena perempuan dianggap sebagai aset berharga sebuah rumah tangga, pekerja yang tekun, mesin reproduksi. Dalam sistem belis ini, yang terjadi adalah pergeseran cara pandang yang berbeda. Belis menempatkan posisi perempuan sebagai layaknya sebuah produk dagang. Perempuan yang dinikahkan seolah-olah diberi harga tertentu oleh pihak keluarga, dan harga itulah yang harus dibayarkan oleh laki-laki.

Harga belis ditentukan berdasarkan tingkatan sosial dari calon pengantin perempuan di masyarakat Sumba. Apabila ia termasuk dalam tingkatan sosial maramba maka belis yang diminta semakin besar bahkan mencapai puluhan ekor kuda dan kerbau. Perempuan dalam tingkat sosial kabihu/kabisu (masyarakat biasa Sumba) akan diminta 5-15 ekor kuda dan kerbau, belum termasuk propertiproperti lainnya seperti parang, tombak maupun mamoli. Apabila termasuk dalam tingakatan ata (budak) maka belis akan dibayarkan oleh tuannya (maramba).

Selain kelas sosial, besaran belis juga ditentukan berdasarkan pendidikan seorang perempuan. Semakin tinggi pendidikan perempuan maka belis yang harus dibayar akan semakin tinggi. Sistem belis ini menyebabkan banyaknya kasus kekerasan yang rentan terhadap anak dan perempuan karena laki-laki merasa sudah membayar belis. Laki-laki merasa bahwa ia layak untuk memperlakukan apa saja kepada perempuan termasuk juga kekerasan. Ini dianggap sebuah hal biasa di masyarakat Sumba sebagaimana gambaran seorang tokoh masyarakat di Sumba Timur bernama Umbu Guntur (Nafi et al., 2016: 249). Umbu Guntu mengatakan bahwa di Sumba Timur tidak ada kekerasan terhadap perempuan karena tindakan yang dilakukan tersebut merupakan hal yang legal menurut adat.

Di Sumba, poligami tidak dilarang oleh adat. Hanya saja, terdapat beberapa syarat yang harus dipenuhi oleh seseorang yang hendak melakukan poligami. Tujuan poligami adalah mempunyai anak putri. Apabila istri pertama mandul, si suami diperkenankan untuk mengambil istri yang kedua untuk kelangsungan keturunannya.

Apabila seorang suami tidak mempunyai anak putri, sedang ia ingin keluarganya menjadi sumber kuturunan, menjadi pihak pemberi gadis (loka), maka poligami dibolehkan. Hanya saja, ada syarat berikutnya, yakni tidak mempunyai saudara perempuan yang mempunyai anak putri lebih dari satu untuk dijadikan anak pungutnya. Selain itu, poligami harus terlebih dahulu mendapatkan izin dari istrinya yang pertama. Calon suami juga harus memberikan belis kepada keluarga perempuan yang dijadikan istri kedua. Tanpa belis, istri kedua yang dinikahi tidak sah, anak anaknya akan tidak mempunyai hak waris sama sekali.

Poligami dapat pula terjadi karena pertimbangan lain, yaitu apabila istri pertama tidak mampu mengurus sawah ladang suaminya yang amat luas. Untuk meringankan beban istri pertama dalam mengurus sawah ladangnya, seorang suami dapat mengambil istri kedua. Bahkan adakalanya, justru istri pertama yang menyarankan agar suaminya mengambil istri kedua.

Motif lain dari poligami di Sumba adalah kekuasaan dan status sosial. Poligami digunakan oleh para bangawan untuk menyatakan status sosialnya dan harta kekayaan yang dimilikinya. Memiliki lebih dari satu orang istri menandakan ia sebagai bangsawan yang kaya raya. Poligami yang dilegalkan oleh adat ini memberikan posisi perempuan berada di bawah laki-laki, dan hanya digunakan 
sebagai alat untuk mengurus ladang serta memberi pangan ternak.

Pemahaman belis sebagai alat tukar untuk "membeli" perempuan memungkinkan eksploitasi perempuan. Belis disamakan dengan membeli lahan. Pemilik lahan dapat menggarap, menanam, bahkan menelantarkan lahan miliknya. Masyarakat Sumba yang rata-rata memiliki mata pencarian bertani, menenun, beternak dan menggantungkan hidupnya kepada alam menganggap perempuan seperti alam. Alam yang perawan, belum terjamah dapat dikuasai, diolah, dan diambil hasilnya untuk kepentingan laki-laki. Hukum legalitas pernikahan perempuan tidak pernah mendapatkan surat nikah secara hukum sehingga menyudutkan perempuan ketika menjadi korban kekerasan.

Barang yang diberikan pihak lakilaki diasosiasikan sebagai benda yang maskulin seperti kuda, kerbau, parang, tombak, dan mamoli (perhiasan yang sering dipakai yang menggambarkan rahim perempuan). Sementara pihak perempuan, apabila menyetujui belis akan memberikan barang balasan belis yang sering diasosiasikan sebagai benda-benda feminin seperti babi dan kain tenun kepada pihak laki-laki. Setelah sistem belis selesai maka laki-laki dan perempuan tersebut sudah resmi menjadi suami istri.

Kaitan mitos mengenai belis dengan film ini dapat dilihat dari kepekaan serta perasaan Marlina ketika mendapat perlakuan dominasi dan eksploitasi yang dilakukan oleh Markus. Marlina mempertahankan haknya sebagai perempuan dan pengelolah alam. Berikut penjelasan singkat yang telah dirangkum oleh peneliti mengenai mitos sistem belis dalam perspektif intuisi.

\section{Gambar 2. Mitos Sistem Belis Perspektif Intuisi \\ (Sumber: Hasil Riset, 2018)}

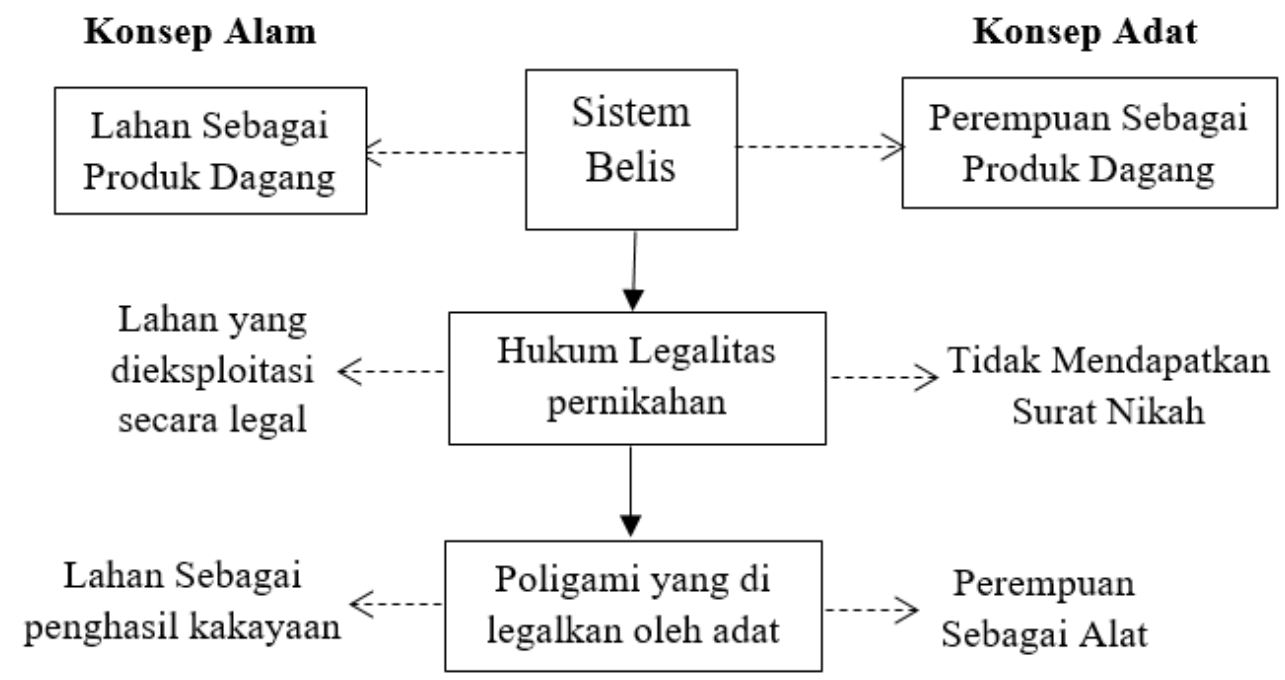

\section{Mitos Kepercayaan Merapu}

Walaupun di Sumba sudah banyak kepercayaan agama yang masuk seperti Kristen, Katolik, Buddha maupun Islam, namun kepercayaan Marapu merupakan kepercayaan yang paling banyak dianut oleh masyarakat Sumba hingga saat ini.
Menurut Soelarto (n.d), kepercayaan Marapu merupakan kepercayaan dengan menyembah para dewa, arwah atau roh nenek moyang di negeri Marapu yang menghuni seluruh penjuru dan ruang alam. Dewa, arwah atau nenek moyang mempunyai kekuatan gaib, magis yang 
mempengaruhi kehidupan manusia di alam semesta.

Kepercayaan Marapu dapat dikatakan merupakan perpaduan unsur-unsur animisme (baik benda bernyawa maupun tidak mempunyai sebuah roh), spiritisme (berkomunikasi dengan roh) dan dinamisme (pemujaan terhadap roh nenek moyang).

Marapu ini merupakan arwah para leluhur yang bertindak sebagai perantara antara manusia dengan Illahi. Hal ini tercermin dari berbagai upacara adat yang dilakukan ketika peristiwa-peristiwa yang bersangkutan seperti adat bercocok tanam, kelahiran, perkawinan, kematian dan lainlain.

Di masyarakat Sumba, setiap orang yang meninggal dunia akan menjadi sosok Marapu atau orang yang dimuliakan dan dianggap sebagai roh leluhur. Dalam kaitan ini, dapat disimpulkan setiap orang dapat menjadi sosok marapu yang dimuliakan oleh anak cucunya.

Roh seorang yang mati secara wajar ataupun gugur sebagai pahlawan hanya bisa mencapai leluhurnya apabila dosadosa semasa hayatnya ditebus dengan persembahan. Persembahan itu biasanya berupa sejumlah hewan korban. Lalu, ia harus memenuhi segala upacara-upacara kematian, serta penguburan menurut tatacara yang berlaku dengan bimbingan doa mantra para ratu (bangsawan) yang berwenang. Apabila hal tersebut tidak dapat dipenuhi, roh tersebut akan menuju ke alam makhluk halus yang buruk, dan akan bergabung dengan makhluk halus yang jahat selalu berusaha mengganggu kehidupan manusia.

Roh yang dimaksudkan dalam kepercayaan Marapu terdiri dari dua unsur yaitu disebut sebagai dewa atau ndewa, dan yang disebut sebagai mawo, samaeo, atau hamangu, hamau.
Dewa atau ndewa sebagai unsur pertama ini menjadi penghuni negeri Marapu yang memiliki kepribadian utuh. Ia punya kedudukan yang sama seperti semasa hidupnya di dunia. Mawo, samawo, atau hamangu, hamau akan tetap berada di dunia sebagai makhluk halus yang menghuni di dalam atau sekitar tempat tinggal sanak keluarganya. Unsur kedua ini terdapat pada manusia, sedangkan yang unsur pertama terdapat pada seluruh makhluk hidup termasuk tumbuh-tumbuhan yang kelak juga ikut menghuni negeri marapu.

Marapu memiliki konsepsi tata hidup alam semesta seperti keseimbangan atau harmoni. Konsepsi ini dianggap mewujudkan keselarasan dan kebahagiaan untuk masyarakat. Kepercayaan ini wajib dipelihara agar tidak menimbulkan hal-hal yang merusak tata hidup. Pelanggaran asas-asas kepercayaan atau adat merupakan dosa yang besar dan akan menimbulkan ketidakseimbangan malapetaka dahsyat.

Pelanggaran dosa besar itu, misalnya, perkawinan Sumbang (saudara). Hal ini akan mengakibatkan kerusakan sendi tatanan masyarakat. Marapu, para arwah leluhur dan mahluk-mahluk halus, akan murka karena kehilangan keseimbangannya. Malapetaka dahsyat berupa kelaparan danwabah akan menimpa masyarakat. Maka, perlu dilakukan pengakuan dosa di muka umum. Upacara pengampunan dosa ini disertai dengan tebusan hewan korban dan bendabenda tertentu. Untuk para arwah yang belum sampai di negeri Marapu, akan dilakukan upacara pengampunan dosa bagi semua arwah tersebut disebut urata yang diselenggarakan setahun sekali di setiap kampung dan desa. Mitos ini ada dalam adegan film Marlina. Hal itu terlihat dalam Kematian (Suami Marlina) dan 
Kelahiran (Novi yang sedang mengandung).

Menurut ajaran Marapu, jenazah harus dibungkus dengan sebuah kain tenun yang berasal dari Sumba. Ia diposisikan seperti layaknya bayi dalam kandungan, yaitu duduk meringkuk. Posisi ini mengajarkan bahwa manusia ketika meninggal harus dikembalikan lagi posisinya ketika berada di dalam kandungan ibunya. Dalam Sumba, posisi meringkuk ini adalah kelapangan hati, kemurahan, belaskasih, pemeliharaan, dan penerimaan dari sang Illahi.

Seperti diketahui, dalam kepercayaan Marapu, keharmonisan dan keseimbangan hidup tercapai dengan memelihara hubungan baik atau kerja sama antara manusia dengan alam. Namun, hal ini kadang dijadikan sebagai batu loncatan untuk melakukan penindasan terhadap perempuan dan alam.

Film Marlina memperlihatkan perempuan pengelola alam memiliki sifat yang feminine. Hal itu ditunjukkan ketika Marlina menangis dan bersandar di samping mayat suaminya. Marlina seakan sedang memberitahukan kepada roh suaminya akan keadaan yang ia rasakan pada saat itu. Marlina kemudian melakukan penebusan dosa dengan membawa kepala yang ia penggal ke kantor polisi.

Shiva (dalam Chandraningrum, 2015: 160) menjelaskan bahwa perspektif ekofeminisme penuh dengan dimensi spiritualitas dalam memandang alam secara feminin. Perempuan mempunyai pengaruh yang penting atas alam karena memiliki sifat feminin yang mampu memelihara dan menciptakan kehidupan alam.

\section{Gambar 3. Mitos Kepercayaan Marapu Perspektif Spiritual}

(Sumber: Hasil Riset, 2018)

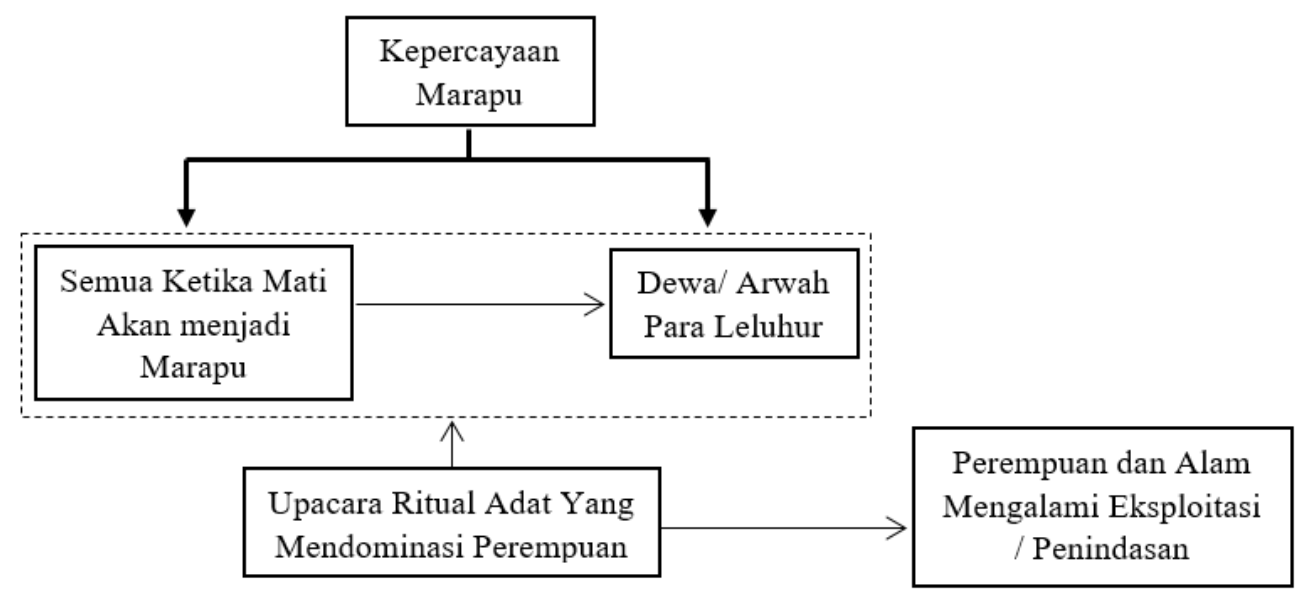

Jadi, presentasi perempuan dalam perspektif pengetahuan, intuisi dan spiritual yang berada di Sumba ini masih menganggap perempuan seperti halnya dengan alam di mana perempuan dan alam diperlakukan semena-mena. Ini memberikan kerugian kepada perem- puan sebagai pengelola alam. Lingkungan yang berada di Sumba ini dianggap berdampak langsung kepada perempuan seperti yang tergambarkan dalam film "Marlina, si pembunuh dalam empat babak”. 


\section{Penutup}

Representasi perempuan pada film ini berdasarkan dimensi pengetahuan memperlihatkan Marlina sebagai pengelola alam yang diibaratkan sebagai tanah tak bertuan yang dapat dikuasai, dijajah, diperkosa, dan diambil kekayaan alamnya

Menurut dimensi intuisi, Marlina ditampilkan sebagai produk dagang yang dapat perlakukan semena-mena. Dalam dimensi spiritual, perempuan digambarkan mengatasi masalah patriarki dengan mengedepankan sisi feminin yang lemah lembut, kasih sayang dan anti dominasi. Ini juga dapat dilihat dari kelahiran bayi yang dikandung oleh Novi, serta kematian yang dialami oleh Markus dan para perampok dianalogikan sebagai akibat yang akan terjadi ketika perempuan dan alam ditindas, di jajah, ataupun dieksploitasi.

\section{DAFTAR PUSTAKA}

\section{Buku}

Candraningrum, Dewi. (2013). Ekofeminisme Dalam Tafsir Agama, Pendidikan Ekonomi, dan Budaya.Yogyakarta: Jalasutra.

(2014). Ekofeminisme II Narasi Iman, Mitos, Air, dan Tanah.Yogyakarta: Jalasutra.

(2015).

Ekofeminisme III Tambang, Perubahan Iklim dan Memori Rahim.Yogyakarta: Jalasutra.

Sugiyono. (2009). Metode Penelitian Pendidikan. Bandung : Alfabeta

Soelarto, B. Budaya Sumba Jilid I. Jakarta: Proyek Pembangunan Ditjen Kebudayaan Departemen P \& K Republik Indonesia (E-Book).

Tong, Rosmarie Putnam. (2008). Feminist Thought: Pengantar Paling Komprehensif Kepada Arus Utama Pemikiran Feminis. Yogyakarta: Jalasutra.

\section{Jurnal}

Mulyoutami, Elok, Gerhard Sabastian, dan James M Roshetko. (2016). Pengetahuan dan Persepsi Masyarakat Pengelola Padang Savana Sebuah Kajian Gender di Sumba Timur. Working Paper. https://www.worldagrofo restry.org/publication/pengetahu an-dan-persepsi-masyarakatpenge lola-padang-savanasebuah-kajian -gender-di (diakses 12 Desember 2018, pukul 21.37 WIB).

Nafi, Tien Handayani, Lidiwina Inge Nurtjahyo, Iva Kasuma, Titawening Parikesit, \& Gratianus Prikasetya Putra. (2016). Peran Hukum Adat Dalam Penyelesaian Kasus-Kasus Kekerasan Terhadap Perempuan Di Kupang, Atambua, Dan Waingapu. Jurnal Hukum dan Pembangunan. Vol 46 No 2 E-ISSN:25031465. 
Pondaag, Illona Grace Undap, Akhasania, Noveina Silviyani Dugis. (2016). Menindas perempuan melalui alam (representasi perempuan dan alam dalam perspektif ekofeminisme dalam film "Maleficent"). Jurnal Komunikatif. Vol 6 No 2. 15.26 WIB)

Wulan, Roro Retno. (2018) Kehidupan Perempuan di Perkebunan Teh, Sebuah Kajian Ekofeminisme. Jurnal Ilmu Komunikasi, Study Gender. Diambil: Dokumen Pribadi.

\section{Internet}

Johannis, Frangky. (2018). Sumba timur urutan kedua kasus kekerasan terhadap perempuan dan anak. [Internet]. Diambil: http://www.victorynews.id/Sumb a-timur-urutan-kedua-kasuskekeras an-terhadap-perempuandan-anak/ (diakses 30 Agustus 2018, pukul 11.29 WIB) 
Jurnal komunikasi, Volume 13, Nomor 2, April 2019, Hal 151-164 